\title{
Children's Books by Canonical Authors in the EFL Classroom
}

\author{
Elena Ortells ${ }^{1}$ \\ ${ }^{1}$ Department of English Studies, Universitat Jaume I of Castelló, Castelló de la Plana, Spain \\ Correspondence: Department of English Studies, Universitat Jaume I of Castelló. Avda Sos Baynat, s/n. 12071 \\ Castelló de la Plana, Spain.
}

Received: September 22, 2020

Accepted: October 21, 2020

Online Published: October 27, 2020

doi: 10.5539/elt.v13n11p100

URL: https://doi.org/10.5539/elt.v13n11p100

\begin{abstract}
Students' imperfect grasp of the target language is cited by educators as one of the main tenets and conundrums against the use of real literature in the EFL classroom. However, previous reviews have proven that children and teenagers are likely to become interested in texts of their own choice and in line with their current concerns. Hence, since encouraging them to read for pleasure and providing them with motivating and level-appropriate materials are basic requirements for success, instructors should receive essential support on how to supply their students with literary texts suitable for both their language level and interests. My intention in this article is thus two-fold. On the one hand, I aim to provide several strategies to overcome the negative attitudes against the use of real literature in the EFL classroom, which are deeply rooted in the educational community, by equipping educators with a theoretical framework that allows them to critically select the most appropriate literary materials for their students. On the other hand, my intention is to present in-service teachers with an illustrative sample of texts and activities that clearly show that authentic literature can be successfully implemented in the teaching sphere.
\end{abstract}

Keywords: canonical authors, children's literature, EFL classroom

\section{Introduction}

A literate population is fundamental to economic progress. Moreover, as defended by UNESCO, further socio-psychological benefits of literacy include self-esteem, confidence, personal empowerment and increased civic engagement (2005). According to numerous studies, reading stimulates comprehension, expands vocabulary, enhances writing skills, encourages intercultural understanding and universal knowledge and boosts students' motivation and confidence (Bland \& Lütge, 2013; Bland, 2018; Grabe, 2009; Krashen, 2004, 2007, 2013; Krashen \& Bland, 2014; Lee, 2015; Ortells, 2017). Furthermore, experiments conducted by West and Stanovich evince that extensive readers have more cultural literacy (West, Stanovich \& Mitchell, 1993) as well as more practical knowledge (Stanovich \& Cunningham, 1993) than non-readers. In addition, Saccardi (2014) underlined the fundamental role that reading plays in the development of critical thinking and creativity. In fact, this author defended the importance of reading literary texts in the creation of "creative or divergent thinkers" (2014, xvi). A "creative or divergent thinker" is "one who pushes the limits of knowledge and ability, is intrinsically rather than extrinsically motivated [...], is able to reframe a problem in order to see it in a different light, and can block out unproductive distractions" (ibid.). As Sir Ken Robinson, renowned education and creativity expert, asserted: "Creativity is as important now in education as literacy and we should treat it with the same status."

Nevertheless, in a society that is deeply influenced by visual resources, making the reading experience enjoyable for children and teenagers becomes a difficult task which results even more challenging among young learners of English as a Foreign language. Hence, Krashen's "Compelling Comprehensible Input” (2011) becomes crucial to promote the use of literary texts in the EFL classroom. According to this hypothesis, "optimal input is compelling, so interesting that the acquirer is hardly aware that it is in a different language, so compelling that the reader is 'lost in the book' (Nell, 1988) or 'in the reading zone' (Atwell, 2007)" (Krashen \& Bland, 2014, 2). Thus, an effective input seems critical to encourage reading among this audience.

Learners' imperfect grasp of the target language is cited by educators as one of the main tenets and conundrums against the use of real literature in this context. However, previous reviews have proven that children and teenagers are likely to become interested in texts of their own choice and in line with their current concerns. The findings of international research suggest that when reading is presented as interesting, fun and achievable, children are more likely to choose to read. In this view, the more children read, the more proficient they become, and the more literate 
they are, the better the educational outcomes will be (Clark \& Rumbold, 2006, 5). Hence, since encouraging them to read for pleasure and providing them with motivating and level-appropriate materials are basic requirements for success, instructors should receive essential support on how to supply their students with literary texts suitable for both their language level and interests (Ortells, 2017, 45).

My intention in this article is thus two-fold. On the one hand, I aim to provide several strategies to overcome the negative attitudes against the use of real literature in the EFL classroom, which are deeply rooted in the educational community, by equipping educators with a theoretical framework that allows them to critically select the most appropriate literary materials for their students. On the other hand, my intention is to present in-service teachers with an illustrative sample of texts and activities that clearly show that authentic literature can be successfully implemented in the teaching sphere.

\section{Theoretical Framework}

Although the language factor (Note 1) seems to be pivotal for integrating authentic literature in the EFL classroom, literary texts also provide many more didactic benefits. In fact, in her introduction to Using Literature in English Language Education. Challenging Reading for 8-18 Year Olds, Janice Bland states that those educational values include "intercultural understanding, empathy, multiple literacies, an understanding of the connectedness of the world and global issues, tolerance, cognitive and affective gains and self-reliance" $(2018,1)$. It therefore seems obvious that intercultural/transcultural (Note 2) and personal growth issues should be an essential part of the texts selected and the activities proposed.

Narratives are important because it is through them "that we learn about ourselves and prepare ourselves for the future" (Hunte \& Golembiewski, 2014, 75). Thus, if literary texts are considered "significant cultural artefacts with an ideological impact on our students" (Gray, 2016, 99), our selection should consist of a myriad of samples that reflect worldwide experiences and seclude reductionist visions of humankind. This is the reason why, in order to lay the ideological foundations which undergird the variety of literary works presented below, I opted for an interactive methodology based on a combination of reader response theory (Fish, 1980; Iser, 1978; Rosenblatt, 1976), cognitive criticism (Nikolajeva, 2014) (Note 3), critical multicultural pedagogy (Freire, 1970; Giroux, 1997; Jupp \& Sleeter, 2016) and critical content analysis (Johnson, Mathis \& Short, 2017; 2019).

First, reader response theory underlines the active role of the reader, enhancing both the autonomy and the critical skills of the learning subject. Similarly, cognitive criticism places the reader at the center of the literary transaction and aims to explore how cognitive and affective skills can be improved and hastened by reading fiction (Nikolajeva, 2014, 19). According to this interdisciplinary approach, when reading fiction, the brain reacts as if the events portrayed were real, that is, "reading fiction makes the brain simulate cognitive and affective responses to the actual world." (ibid.). Consequently, drawing connections between fictional knowledge and real-life knowledge can contribute to improving the readers' understanding of the real world (Nikolajeva, 2014, 8). Additionally, critical multicultural pedagogy destabilizes hierarchical race and gender constructions and fosters awareness of diversity and respect for pluralism (Ortells, 2017, 48). Finally, the foundations of critical content analysis rely on a political stance which allows the reader to reflect upon issues of inequity and power (Johnson et alii, 2019, 5) and to consider literary pieces as "products of particular historical and cultural contexts" (Johnson et alii, 2017, 196). Thus, since critical content analysis focuses on the study of the sociopolitical role of language in texts, it constitutes an exceptional tool for students to understand other perspectives and cultures and to take a more questioning stance towards themselves, their experiences and their worlds. The combination of these four approaches will set the basis for the variety of texts proposed in the following section.

\section{A Selection of Children's Books by Canonical Authors}

Once the theoretical lenses had been defined, the next step consisted in gathering a set of texts, which rendered themselves suitable for the proposal. In order to do so, a distinct series of criteria was required. Bland's directives turned out to be extremely valuable again since, in less than a page, they hinted at the basics that instructors should take into consideration when selecting appropriate materials for each group, in terms of age-related schemata, interests and language competence. Roughly speaking, the text should be accessible to students and capable of engaging them in discussion on motivating and relevant issues; it should possess literary value and draw connections with diverse historical periods, nations and/or cultures; it should have at its center characters with whom their readers can easily empathize, and last but not least, the teacher should be passionate about it (2018, 12).

Taking into consideration all these issues, I finally decided to focus on books written specifically for children by authors who are canonical but not considered children's writers. Works such as Virginia Woolf's The Widow and the Parrot (1982) (Note 4), James Baldwin's Little Man, Little Man, a Story about Childhood (1976) (Note 5), or 
Salman Rushdie's Haroun and the Sea of Stories (1990) (Note 6) offer an insight into this sort of books. I began examining literary pieces that fitted the category mentioned above and, from my initial forays, I compiled a list of works written by authors such as Mark Twain, Toni Morrison, Chinua Achebe, Lucille Clifton, Anita Desai, Sandra Cisneros, or Amy Tan. From these names, it can be seen that the term 'canonical' is being used in its widest sense and that the selection of writers presented tries to provide educators with a clearer sense of the true diversity of the English-speaking world. Besides the possibility of working on linguistic, cultural and personal growth issues (Carter \& Long 1991), the children's books written by these artists have the added value of making students conversant with relevant figures in literary history, of being acquainted with the literary movements these authors belonged to, and of becoming familiar with the social and historical contexts in which their works originated.

Selecting the texts entails a thorough research process, exploring many options before deciding on a series of pieces, based on specific criteria. Hence, regardless of how attractive they might have appeared initially, some of the books cited above proved inadequate in terms of age appropriateness, students' interests and/or language complexity. This served as a clear reminder of the need to bear these issues in mind when selecting materials for the EFL classroom. Let us draw, for instance, on my choice of Mark Twain's "Advice to Little Girls" (1867) to illustrate this point. My initial objective when picking this short story was primarily to introduce a relevant figure in American literary history and his use of satire to deal with the gender ideology of his time. Since the text might present certain difficulties in terms of language, I resorted to two beautifully illustrated editions - Vladimir Radunsky and Frank M. Hansen's Advice to Little Girls by Mark Twain - as visual images become extraordinary allies in the EFL classroom, enhancing stories and providing additional information (Johnson et alii, 2019, 7).

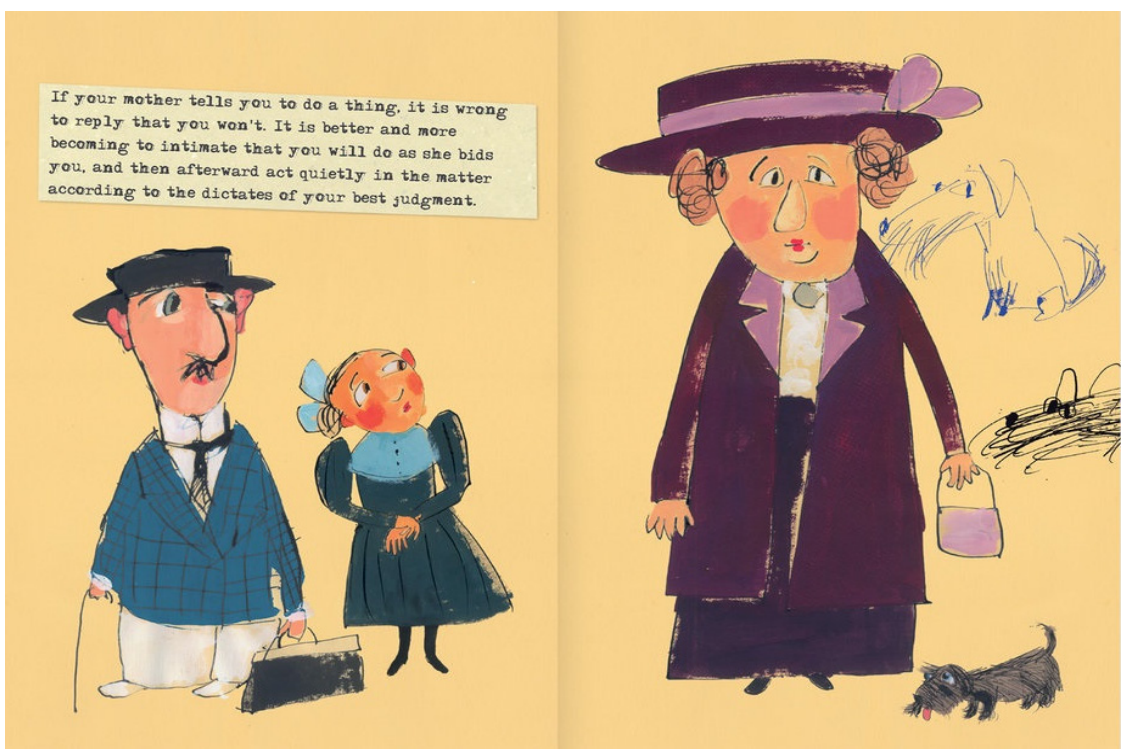

Figure 1. From Vladimir Radunsky's Advice to Little Girls by Mark Twain

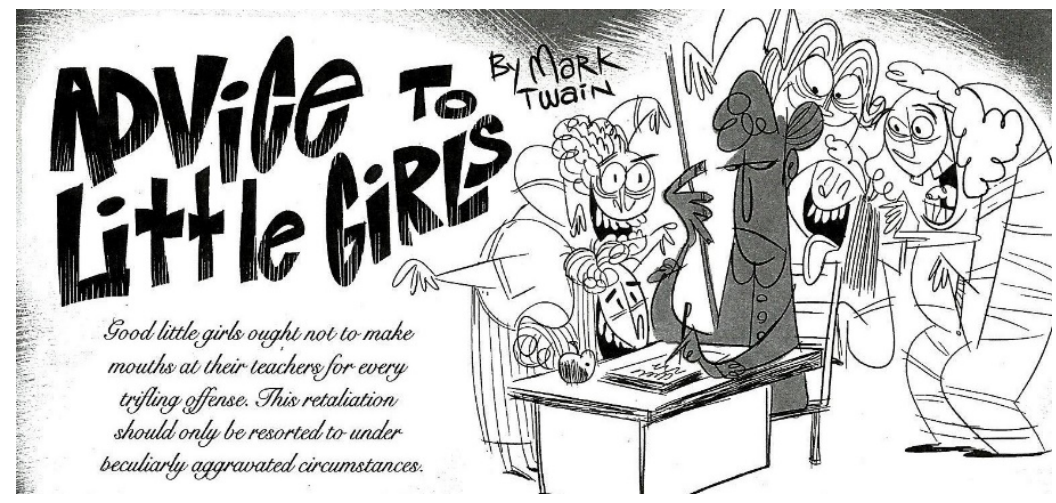

Figure 2. From Frank M. Hansen's Advice to Little Girls by Mark Twain 
However, although it is obvious that the interplay between words and images may facilitate the understanding of the text, still its linguistic complexity may end up in leaving students discouraged and lacking any kind of motivation. It is for this reason that I would finally preclude this work from the initial list of recommended pieces.

Conversely, Toni and Slade Morrison's The book of mean people (2002) serves as an example of a book in which images act as powerful tools to create meaning, working on basic linguistic aspects - adjectives, in this case - and instilling values "that are in keeping with a liberal ideal of education" (López Ropero, 2008, 47) at the same time. This illustrated book was the result of the collaboration between Nobel-Prize winner Toni Morrison and his son, Slade, and echoes the ideological foundations of John Dewey (1990) and Martha Nussbaum (2003), among others. Their philosophy of education relied heavily on encouraging children's independent thinking and autonomy. Although Morrison's work integrates topics and characteristics that are distinctive of African American children's literature, she intended to target a more universal audience, addressing worldwide experiences.

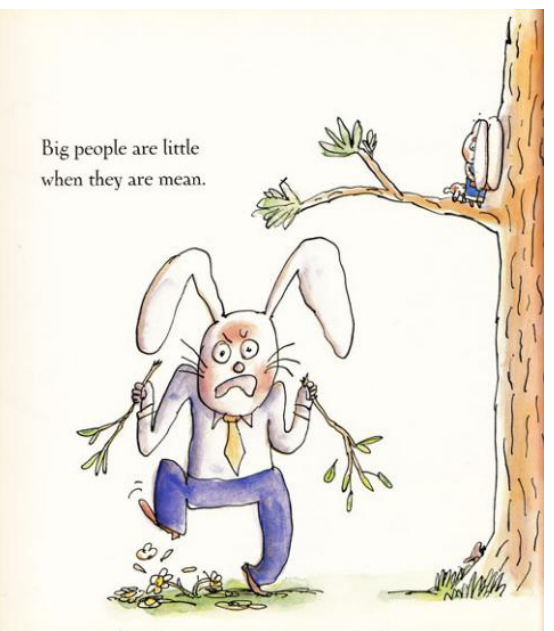

Figure 3. From Toni and Slade Morrison's The book of mean people (2002)

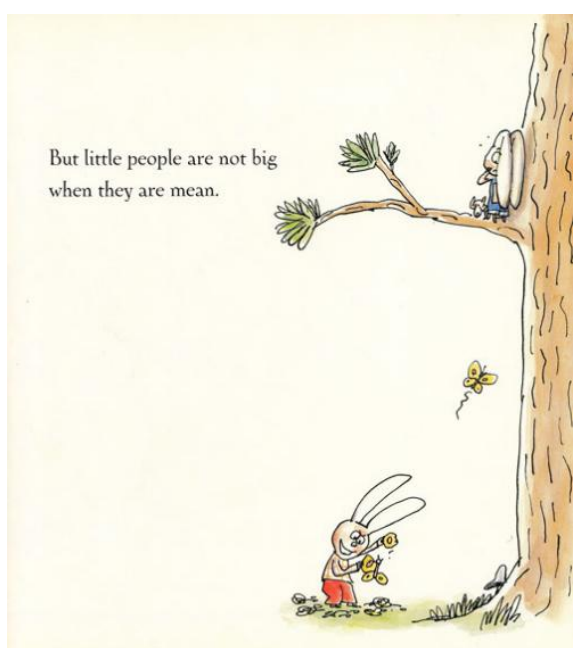

Figure 4. From Toni and Slade Morrison's The book of mean people (2002)

Chinua Achebe, one of the first African authors to give a realistic and non-prejudiced image of Nigerian life in Things fall apart, is also the author of Chike and the river (1966), a book about an eleven-year-old Nigerian boy who tries to make his way from the village where he lives to the city of Asaba. This book works as an example of a phenomenon that took place in Africa in the 1960s and 1970s, that is, the need for locally relevant reading materials for schoolchildren. Some African authors - and Chinua Achebe was an example of this attitude - felt the need to write stories that reflected the everyday life of part of the Nigerian population. The following excerpt serves as an exceptional example to make students reflect upon intercultural differences and show their opinions on controversial gender issues:

Chike was so anxious to find the money for his trip across the river that he very nearly went into bad ways. 
One of his friends called Ezekiel was a very bad boy. Like Chike, Ezekiel was his mother's only son. He had four sisters. Ezekiel's mother was a well-to-do trader who sold cloth in the Onitsha market and made much profit. But she was not a wise mother [...] His mother had three servants who did all the housework. Sometimes Ezekiel's sisters were asked to wash plates or draw water from the public tap. But he never did any work. His mother said that housework was only for servants and for girls (1966, 17-18).

First published in 1969, Langston Hughes's Black misery played a key role in developing a literature designed to encourage black children to feel proud of their heritage. Reading some of the pages of this delightfully illustrated book can help learners to understand the long history of police brutality and racial discrimination experienced by African Americans in the United States. Quotes such as "Misery is when you start to help an old white lady across the street and she thinks you're trying to snatch her purse" or "Misery is when you heard on the radio that the neighborhood you live in is a slum but you always thought it was home" offer a tragic portrait of the outrageous situation of this ethnic group in America. They also provide a perfect explanation for the overwhelming success of movements such as Black Lives Matter in the light of the recent deaths of George Floyd or Breonna Taylor.

Using a poem for each letter of the alphabet in The black BC's (1970), Lucille Clifton, one of the frontrunners in the creation of late 20th-century African American children's literature, introduces brief discussions of the contributions of black people to American history and culture: "Clifton uses The black $B C$ 's to convey revisionist history and an affirmation of black life to young readers who might initially think that they are reading just another simple ABC book" (Martin, 2012, 56). However, Clifton's intention was to offer young African American readers an alternative to the long tradition of $A B C$ books, whose cultural associations were predominantly white and were very much in line with the Dick and Jane series (Note 7). Thus, to counteract this tendency, she introduced concepts such as "Middle Passage" (1970, 25), "Slavery" (1966, 35), or "Underground" (1966, 39):

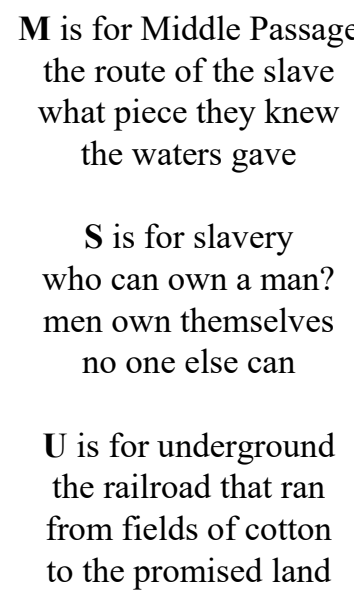

These poems were accompanied by drawings and brief explanatory notes of the terms illustrating each of the letters of the alphabet: i.e. The following annotation was intended to clarify the word "Underground": "The Northerly route that escaping slaves used to travel to freedom was called the Underground Railroad. Along their way, fugitives were aided by many undercover agents who hid them and slipped them through to the next Underground Railroad station. The unofficial president of the Underground Railroad was a Quaker gentleman named Levi Coffin" (1970, 39).

Sara Jane Boyers' edition of Life doesn't frighten me at all (1993) represents a wonderful opportunity to expose young learners to the rhythm, rhyme and themes of Maya Angelou's poetry. Written from the perspective of a child, the lines reflect basic fears in childhood (darkness, bullying, etc.):

Shadows on the wall

Noises down the hall

Life doesn't frighten me at all

[...]

That new classroom where

Boys all pull my hair

(Kissy little girls 
With their hair in curls)

They don't frighten me at all.

Moreover, Angelou's lines are accompanied by the pictorial art of Jean-Michel Basquiat, one of the most important Neo-Expressionist painters in the 1980s, whose illustrations perfectly capture the temper and essence of the work of the African American writer. The conjunction of both poetry and paintings results in an elaborate aesthetical construct that makes of this book exceptional material for literary practice in the EFL classroom.

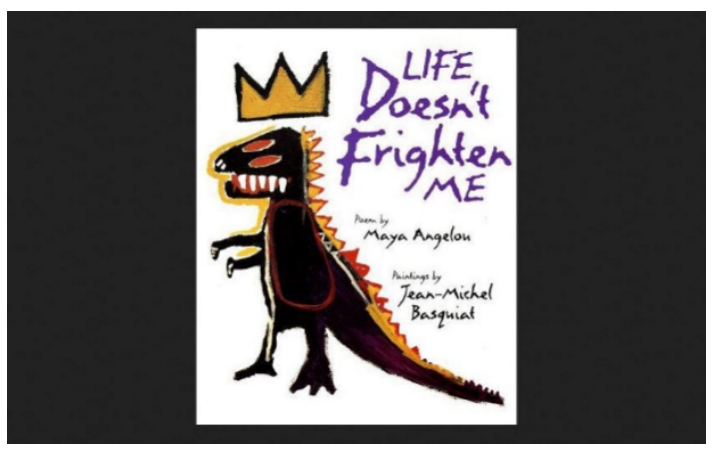

Figure 5. Cover of the book

bell hooks and Chris Raschka's Happy to be nappy (1999) can also be used to implement cultural and personal growth values. This book celebrates a very African trait, nappy hair. The text serves as an introduction to the politics of hair among African Americans and counteracts the derogatory connotations of the word "nappy" in that community. Hence, its final lines are as follows: "Happy with hair all short and strong. Happy with locks that twist and curl. Just all girl happy! Happy to be nappy hair!". This album works as an adaptation for children of the same ideological implications hooks poses in her essay "Straightening Our Hair": "black girls and women should not allow white supremacist ideology to determine how they feel about their hair: nappy is beautiful and they shouldn't straighten it or change it to fit the white beauty standard" (Martin, 2004, 68). Moreover, although initially intended to encourage self-esteem among African American kids, the book likewise boosts general reflections upon issues of beauty, race, self-hatred and self-respect, addressing worldwide audiences.

In writings such as The village by the sea (1982) Indian writer Anita Desai tries to deconstruct Western biased views of India. Fragments such as the one quoted below provide educators with a perfect tool to deal with linguistic, cultural and personal growth issues:

Lila, Bela and Kamal - his three sisters [...]

What were they waiting for? What were they hoping for? They could never look forward to working on a fishing boat or in a factory, as he did. They would have to marry, one day, and he would have to see to it since his father would not. He would have to find them husbands and buy them their wedding finery - silk saris and gold jewelry - and arrange their weddings to which the whole village would have to be invited.

Not only does the brief text allow teachers to work on grammar points - i.e. the use of "would" - but also opens an extraordinary window into life in India, exploring customs and traditions, heavily influenced by class and gender issues. Besides, such controversial matters encourage students' critical thinking and can lead them into the realm of social action.

Finally, in some of their works Mexican American Sandra Cisneros and Chinese American Amy Tan try to reflect upon the identity conflict experienced by children and teenagers of mixed origins. Sandra Cisneros' "Hairs/Pelitos" was originally a vignette, part of a collection of short stories belonging to The house on Mango Street (1984). In this book and mainly through twelve-year-old Esperanza, Cisneros ponders upon what it means to be a Chicano adolescent growing up in the United States. Turned into an illustrated book in 1997, Hairs/Pelitos is extraordinary material to work on in the EFL classroom since the interplay between images and words facilitates the interpretation of the passage. The piece contains brief descriptions of people's hair: i.e. "My papa's hair is like a broom, all up in the air"; "Carlo's hair is thick and straight"; "Nenni's hair is slippery"; "And me, my hair is lazy". These sentences offer a wonderful opportunity to work on linguistic and personal growth issues. On the one hand, the visual portraits of the different members of the family serve as a basis to understand the adjectives that define 
the different types of hair. On the other hand, the overall content message of the fragment clearly undermines physical discrimination and celebrates diversity.

Similarly, Amy Tan and Gretchen Shields's The Moon Lady (1992) is an illustrated adaptation of one of the stories that conform the former's The Joy Luck Club (1989), a novel that reflects upon the potentiality of storytelling and the complexity of Chinese family relationships, especially among the Chinese mothers living in the United States, and their American-born daughters. Hence, the following passage offers an exceptional juncture to deal with linguistic, cultural and personal growth issues in the EFL classroom:

Three sisters looked out the window of their grandmother's apartment [...] "I wish it would stop raining," said Maggie with a sigh [...] "I wish we could get wet," said Lily [...]. "Nai-nai," she [June, the youngest sister] said to her grandmother. "I wish we had something to do."

"So many wishes on a rainy afternoon," Nai-nai said [...]

"Who is the Moon Lady?" asked Lily.

What is a secret wish?" asked June.

"So many questions!" Nai-nai said. "Well, sit down and I will tell you - in a story that comes from my childhood in China. It is my earliest memory." $(1992,1)$.

Besides the obvious exploitation of grammar issues such as the formulation of wishes and the usage of direct speech, this fragment introduces the figure of the Moon Lady, a significant character in Chinese culture, who grants the secret wishes of those who ask, and offers a distinctive perspective on Chinese oral tradition and female family relations.

\section{A Proposal for Activities}

In order to link theory, sample texts and teaching practices, some suggestions will be presented next. Although limited in scope, the activities proposed here go beyond the traditional comprehension questions that accompany most literary texts and rely on a more extensive conception of the term "literacy". In fact, they are intended to promote multiple literacies in the EFL classroom, not just helping children and adolescents learn to read and write (functional literacy) but also promoting the search for information (information literacy), instructing them to appreciate their aesthetic nuances (literary literacy), and to develop their visual literacy (in those texts accompanied by images) and critical potential (critical literacy) (Bland, 2018, 5).

\subsection{Author's Names and Photographs}

This activity does not entail much linguistic or contextual preparation and works very well as an introduction to the authors and literary works which are going to be dealt with. Students should match the photographs of the writers shown below with their names. One principle that should be born in mind by instructors when designing this sort of materials is that for these proposals to be successful, it is vital to make sure that the activities are doable. Consequently, in this case, for instance, students ought to be able to relate authors and photographs with the aid of just their background knowledge, intercultural assumptions and visual literacy.

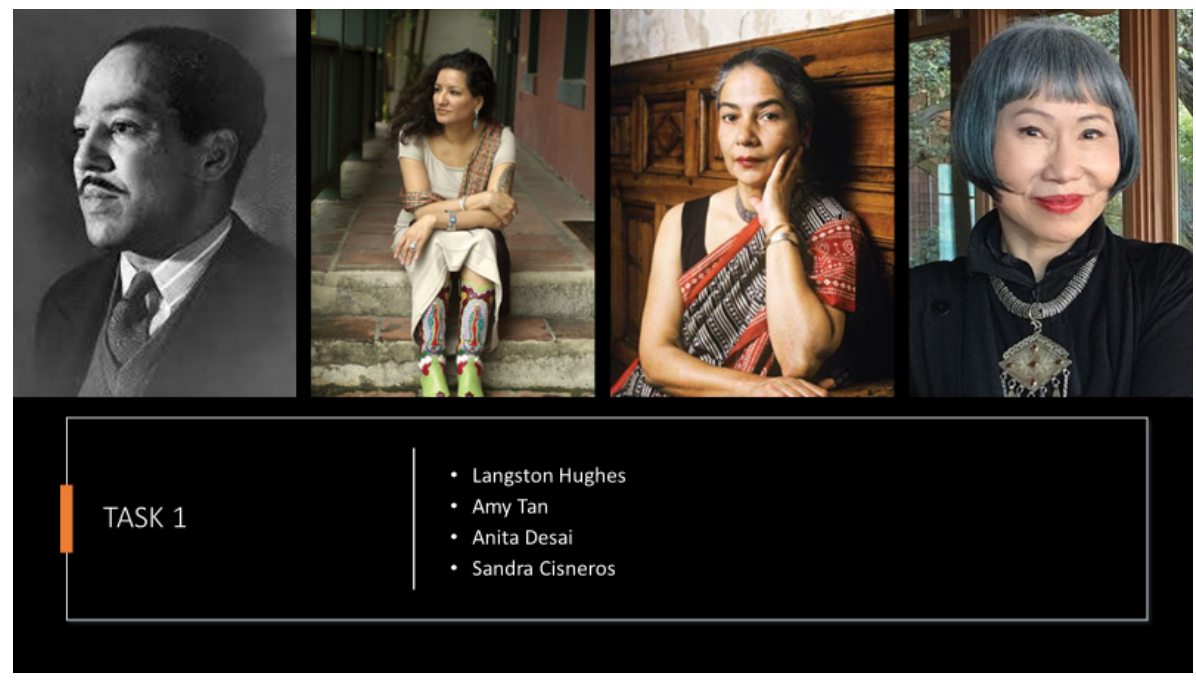

Figure 6. Task 1 
This activity can be used as a starting point to ask students to write a short physical description. If they need some guidance the instructor can provide them with a word cloud containing useful adjectives (Paran \& Robinson, 2016, 54). Additionally, they can be asked to do some research on these authors and connect their lives and backgrounds to relevant historical events and literary movements, thereby facilitating the development of cross-curricular topics. In this way, they can become familiar with the Harlem Renaissance and with issues of black identity through the figure of Langston Hughes. Amy Tan can be useful to introduce the problems faced by Chinese immigrants in the United States and their intergenerational tensions. Anita Desai can be an excellent means to explore the colonial ventures of the British Empire and Indian customs and traditions. Finally, Sandra Cisneros' work can help to acquaint learners with the complex relationship between the United States and Mexico and the circumstances that surround Mexican American female writers in the USA.

\subsection{Authors, Titles and Book Covers}

As a follow-up to the previous activity, students could match authors and titles using book covers as aids. Book covers can indeed be exceptional tools to engage them in lively discussions about the main themes of the literary works selected. For this activity to be successful, the instructor needs to make sure that the name of the author is erased from the cover and that there is enough evidence to help students make the appropriate connections. Instructors also need to remember that if the activity is too challenging, learners will be discouraged from continuing. The covers of Langston Hughes' Black misery, Amy Tan's The Moon Lady, Anita Desai's The village by the sea and Sandra Cisneros' Hairs/Pelitos are extremely valuable ways to introduce customs and traditions worldwide, to arouse insightful reflections about appearances and to celebrate difference. Moreover, Paran and Robinson suggest the use of not just one but of different covers - even of translated versions in different languages - as part of a predicting activity that leads students to reflect upon relevant themes or characters present in the books $(2016,92)$. Besides, the materials needed are extremely easy to find through online searches that learners can also be made responsible for conducting. In-depth analysis of the similarities and differences between the different covers can be extremely helpful to promote not just visual literacy but also to develop critical skills and enhance intercultural knowledge.

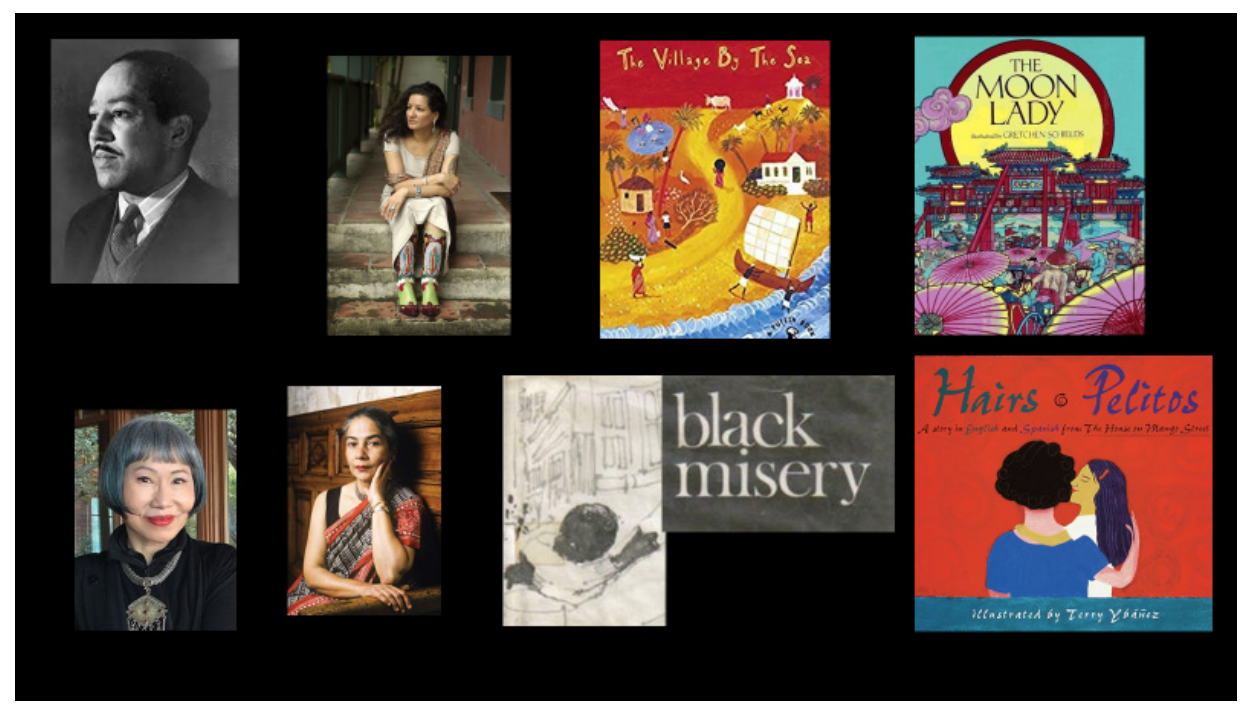

Figure 7. Task 2

\subsection{Authors and Literary Fragments}

We can also design a matching activity in which students decide on the title and authorship of a selection of literary quotes. Teachers need to bear in mind that, in order to motivate students, the activity must be doable and, ideally, the extracts should either contain key words that facilitate the connection with the title and author and/or obvious references to the central topics of the text. Additionally, excerpts could also be used to deal with linguistic issues, illustrate intercultural aspects and encourage creativity, as can be seen in Figure 8. 


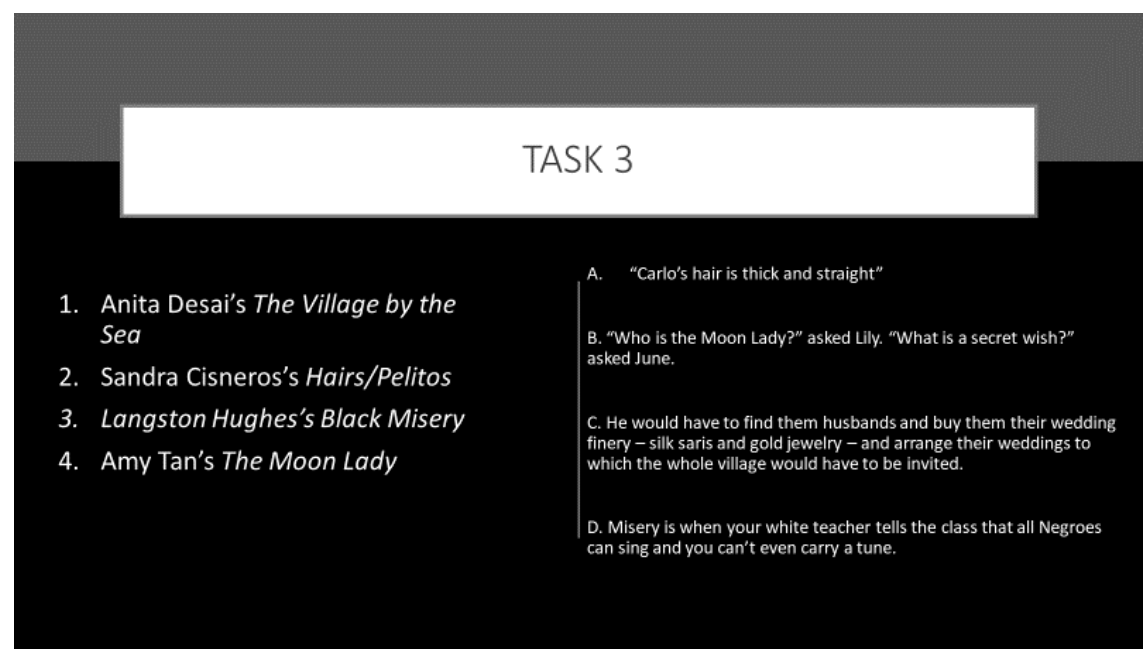

Figure 8. Task 3

\subsection{Walkabout Activity (Note 8)}

This activity is intended to make students walk around the class and engage them into reading a variety of literary fragments that the instructor will have strategically arranged on the walls of the classroom. After reading them all, they will stand next to the one they like best and discuss the reasons for their choice. Then the instructor can ask a few students to comment on their preferences. For this activity to be successful, the texts need to be short and must arouse students' curiosity.

This activity can be used either as a continuation of the previous activities or, alternatively, as an introduction to them, using the fragments as hooks to engage students' in dialogic interactions that lead them to a process of research into the different works and authors presented.

\section{Conclusions}

Although each educator should develop their own analytical tools and design their own materials, I believe this article has proven that reader response theory, cognitive criticism, critical multicultural pedagogy and critical content analysis may play an exceptional role in the choice of effective materials for the EFL classroom. We, as teachers, hold the extraordinary responsibility of selecting texts that serve as windows open to the world, to worlds that are unknown to our students. We should try to avoid the "dangers of a single story" (Ngozi, 2009) and use books as tools to build bridges between cultures. Hence, we cannot exclude ethnic literatures from the canon of children's literature since "learning to read is as much of an ideological process as a means of individuation and personal growth" (Paul, 2009, 128). Selecting pieces that embody cultural diversity thus broadens students' knowledge and highlights issues of ethnicity and difference among learners. Beyond the undeniable linguistic benefits, the texts proposed here were aimed at endowing our students with the distinctive features of an intercultural speaker: "respect, empathy, flexibility, patience, interest, curiosity, openness, motivation, a sense of humour, tolerance for ambiguity, and a willingness to suspend judgment" (Fantini, 2009, p. 198). Classrooms should then become intellectual spaces where critical analysis is undertaken and our students, following Freire's proposal, should become "critical coinvestigators in dialogue with the teacher", rather than "docile listeners" $(1970,81)$ (Ortells, 2017, 48).

I would like to finish by quoting a fragment from a book by Toni Morrison titled Please, Louise to vindicate the power of books as catalysts of the imagination: "A library is a shelter from any storm... These books are loyal friends... Imagination is an open door...". Imagination becomes essential for both knowledge and personal growth. As Albert Einstein said, "Imagination is more important than knowledge. Knowledge is limited. Imagination encircles the world". And we all know that reading gives you the key to imagination. May our choices as educators contribute to the construction of messages of collaboration between races and cultures and help to develop students' critical awareness and understanding. In order to do so, instructors should receive adequate training that enables them to design attractive programs, with distinct objectives and well-defined criteria, and to supply the EFL classroom with appropriate literary materials. Although limited in scope, this article is intended to be a significant contribution to this crucial scheme. 


\section{Acknowledgements}

This work was supported by the Project “Children's and Young Adult American Literature in the $21^{\text {st }}$ Century: Theoretical Analysis and Practical Applications”, funded by Universitat Jaume I UJI-B2018-02 (2019-2021).

\section{References}

Achebe, C. (2011) (1966). Chike and the river. New York: Random House.

Atwell, N. (2007). The reading zone. New York: Scholastic.

Baldwin, J. (1976). Little Man, Little Man, a Story about Childhood. New York: Dial Press. https://doi.org/10.1515/9781478002345

Bland, J., \& Lütge, C. (Eds.). (2013). Children's literature in second language acquisition. London: Bloomsbury.

Bland, J. (Ed.). (2018). Using literature in English language education. Challenging reading for 8-18 year olds. London: Bloomsbury.

Boyers, S. J. (Ed.). Life doesn't frighten me. Poem by Maya Angelou. Paintings by Jean-Michel Basquiat. New York: Stewart, Tabori \& Chang.

Carter, R., \& Long, M. (1991). Teaching literature. London: Longman.

Cisneros, S. (1984). The house on Mango Street. London: Vintage.

Cisneros, S. (1997). Illustrated by Terry Ybáñez. Hairs/Pelitos. New York. Dragonfly Books.

Clark, C., \& Rumbold, K. (2006). Reading for Pleasure: A research overview. National Literacy Trust, 1-35.

Clifton, L. (1970). The black BC's. New York: Dutton.

Desai, A. (1982). The village by the sea. London: Puffin Books.

Dewey, J. (1990) (1900). The school and society. The child and the curriculum. Chicago: The U of Chicago P. https://doi.org/10.7208/chicago/9780226112114.001.0001

Fantini, A. (2009). Developing intercultural competencies: an educational imperative for the 21 st century. Studies in Language and Literature, 28(2), 192-213. Retrieved from http://ci.nii.ac.jp/els/contentscinii_20170512172958.pdf?id=ART0010103652

Fish, S. (1980). Is there a text in this class? The authority of interpretive communities. Cambridge, Mass.: Harvard UP.

Freire, P. (1970). Pedagogy of the oppressed. New York: Continuum.

Giroux, H. (1997). Pedagogy and the politics of hope. Theory, culture and schooling. A critical reader. Boulder, Colorado: Westview Press.

Grabe, W. (2009). Reading in a second language. Moving from theory to practice. Cambridge: CUP. https://doi.org/10.1017/CBO9781139150484

Gray, J. (2016). ELT materials: Claims, critiques and controversies. In G. Hall (Ed.), The Routledge handbook of English language teaching (pp. 95-108). Abingdon, Oxon: Routledge.

Hansen, F. M. (2014). Advice to little girls, Mark Twain. In R. Kick (Ed.). The graphic canon of children's literature. New York: Penguin Random House.

Hooks, b., \& Raschka, C. (1999). Happy to be nappy. New York: Hyperion.

Hughes, L. (1994) (1969). Black misery. Oxford: OUP.

Hunte, B., \& Golembiewski, J. (2014). Stories Have the Power to Save Us: A Neurological Framework for the Imperative to Tell Stories, Arts and Social Sciences Journal, 5(2), 73-6. https://doi.org/10.4172/2151-6200.1000073

Iser, W. (1978). The act of reading: A theory of aesthetic response. Baltimore, MD: The John Hopkins University Press.

Johnson, H., Mathis, J., \& Short, K. G. (2019). Critical content analysis of visual images in books for young people. Reading images. New York \& London: Routledge. https://doi.org/10.4324/9780429426469

Johnson, H., Mathis, J., \& Short, K. G. (2017). Critical content analysis of children's and young adult literature. Reframing perspective. New York \& London: Routledge. https://doi.org/10.4324/9781315651927 
Jupp, J. C., \& Sleeter, C. (2016). Interview of Christine Sleeter on multicultural education: past, present, and key future directions. National Youth-At-Risk Journal, 1(2), 8-26. https://doi.org/10.20429/nyarj.2016.010202

Krashen, S., \& Bland, J. (2014). Compelling comprehensible input. Academic language and school libraries. Children's Literature in English Language Education. CLELE Journal, 2(2), 1-12. Retrieved from https://clelejournal.org/compelling-comprehensible-input/

Krashen, S. (2004). The power of reading. Westport: Heinemann.

Krashen, S. (2007). Extensive reading in English as a foreign language by adolescents and young adults: a meta-analysis. International Journal of Foreign Language Teaching, 3(2), 23-9.

Krashen, S. (2011). The compelling (not just interesting) input hypothesis. The English connection. KOTESOL, $15(3)$.

Retrieved

from http://www.koreatesol.org/sites/default/files/pdf_publications/TECv15n3-11Autumn.pdf

Krashen, S. (2013). Free reading: still a great idea. In J. Bland and C. Lütge (Eds.), Children's literature in second language education (pp. 15-24). London: Bloomsbury.

Lee, S. (2015). Joining the 'literacy club': when reading meets blogging. ELT Journal, 69(4), 373-382. https://doi.org/10.1093/elt/ccv030

López Ropero, M. L. (2008). Trust them to figure it out: Toni Morrison's books for children. ATLANTIS. Journal of the Spanish Association of Anglo-American Studies, 30(2), 43-57.

Martin, M. H. (2012). Brown gold: milestones of African-American children's picture books, 1845-2002. London: Routledge.

Morrison, T., \& Morrison, S. (2002). The book of mean people. New York: Hyperion.

Morrison, T., \& Morrison, S. (2014). Please, Louise. New York: Simon \& Schuster.

Nation, K. (2017). Nurturing a lexical legacy: Reading experience is critical for the development of word reading skill. Science of Learning, 2(3), 1-4. https://doi.org/10.1038/s41539-017-0004-7

Nell, V. (1988). Lost in a book. New Haven: Yale University Press.

Ngozi, C. A. (2009). The danger of a single story. TEDTalk. TEDGlobal. Retrieved from https://www.ted.com/talks/chimamanda adichie the danger_of a single story/transcript\#t-40490

Nikolajeva, M. (2014). Reading for learning. Cognitive approaches to children's literature. Amsterdam: John Benjamins. https://doi.org/10.1075/clcc.3

Nussbaum, M. (2003). Cultivating humanity: A classical defense of reform in liberal education. Cambridge: Harvard UP.

Ortells, E. (2017). Using American coming-of-age stories in the ELT classroom. Children's Literature in English Language Education. Clele Journal, 5(1), 1-12.

Paran, A., \& Robinson, P. (2016). Literature. Oxford: OUP.

Paul, L. (2009). Learning to be literate. In M. O. Grenby (2009) (Ed). The Cambridge companion to children's literature (pp. 127-142). Cambridge: CUP. https://doi.org/10.1017/CCOL9780521868198.008

Radunsky, V. (2013). Mark Twain's “Advice to little girls". New York: Enchanted Lion Books.

Rosenblatt, L. M. (1976). Literature as exploration. New York: The Modern Language Association of America.

Rushdie, S. (1990). Haroun and the sea of stories. London: Granta.

Saccardi, M. (2014). Creativity and children's literature. New ways to encourage divergent reading. Santa Barbara: ABC Clio.

Stanovich, K., \& Cunningham, A. (1993). Where does knowledge come from? Specific associations between print exposure and information acquisition. Journal of Educational Psychology, 85(2), 211-229. https://doi.org/10.1037/0022-0663.85.2.211

Tan, A. (1989). The Joy Luck club. London: Vintage.

Tan, A. (1992). The Moon Lady. Illustrated by Shields, G. N. Y.: MacMillan.

Twain, M. (1867). Advice to little girls. Retrieved from https://americanliterature.com/author/mark-twain/short-story/advice-to-little-girls 
UNESCO. (2005) (19-21 July). Session on literacy and empowerment. Sixth Meeting. Working Group on Education for All (EFA). Paris: UNESCO.

West, R., Stanovich, K., \& Mitchell, H. (1993). Reading in the real world and its correlates. Reading Research Quarterly, 28, 35-50. https://doi.org/10.2307/747815

Woolf, V. (1988) (1982). The widow and the parrot. London: Hogarth Press.

\section{Notes}

Note 1. "Reading is key because 'it provides many different contexts, episodes and experiences which, over time, sum to a rich and nuanced database about a word, its connections to other words and its lexical history within an individual's experience' (Nation 2017: 2)." (Bland, 2018, 6).

Note 2. These two terms are sometimes used interchangeably.

Note 3. Although a variety of labels have been used to refer to a similar concept (cognitive literary theory, cognitive poetics, cognitive narratology and literary cognitivism), I will follow Nikolajeva's conscientious choice of the expression "cognitive criticism" $(2014,3)$.

Note 4. The Widow and the Parrot was part of the archives of The Charleston Bulletin for over fifty years. It was finally published in 1982, in the July issue of Redbook, to celebrate the one-hundredth anniversary of Virginia Woolf's birth. It is a short story about the moral of kindness to animals.

Note 5. It dealt with the daily life of three boys coming of age in Harlem. In this book, written in black vernacular, Baldwin "aims to empower black children by emphasizing family and community bonds, orality, the importance of education, as well as the beauty of blackness" (López Ropero, 2008, 46).

Note 6. A novel about the problems in the Indian subcontinent.

Note 7. I found particularly interesting this activity proposed in https://www.the-best-childrens-books.org/ABC-USA.html

Divide students into groups and have them brainstorm additional (1) historical, (2) cultural, and (3) geographic words about the United States to create their own ABC books. (Have them talk quietly so that each group will come up with their own words.) Once they have a list, groups should divide the list up among themselves, create pages for their words, and once complete, staple them together to create USA ABC books of their own. The possibilities are seemingly endless, i.e:

A could be for Alabama or Abraham Lincoln or Abolitionists or Appalachia...

B could be for Buffalo Bill or Broadway or Boston Tea Party or Baseball...

C could be for California or Cotton Gin or Columbus or Christmas...

Note 8. More details about this activity can be found in Paran, A. \& Robinson, P. (2016, 39-40). 


\section{Appendix A}

\section{More children's (and Young Adult Literature) books written by canonical authors}

Find below a list of recommended titles that can be used in the EFL classroom.

Alexie, S. (2008) (2007). The absolutely true diary of a part-time Indian. London: Andersen Press.

Álvarez, J. (2009). Return to sender. New York: Yearling.

Eliot, T. S. (2015) (1939). Old Possum's book of practical cats. London: Faber \& Faber.

Erdrich, L. (1999). The Birchbark House. New York: Hyperion.

Faulkner, W. (1967). The wishing tree. New York: Random House.

Giovanni, N. (2008) (Ed.). Hip-Hop speaks to children. A celebration of poetry with a beat. Naperville, Illinois: Sourcebooks.

Hughes, L. (1952). The first book of negroes. New York: Franklin Watts.

Hughes, L. (1954). The first book of jazz. New York: Franklin Watts.

Huxley, A. (1944). The Crows of Pearblossom. Illustrated by Cooney, B. New York: Random House.

Morrison, T., \& Morrison, S. (1999). The big box. New York: Hyperion.

Nye, N. S. (1997). Habibi. New York: Simon and Schuster.

Plath, Sylvia. (1976). The bed book. Illustrated by Quentin Blake. London: Faber.

Sandburg, C. (1922). Rootabaga stories. New York: Harcourt, Brace \& Company. https://www.gutenberg.org/files/27085/27085-h/27085-h.htm

Saunders, G. (2000). The very persistent gappers of Frip. Illustrated by Smith, L. New York: Random House.

Sexton, A. (1963). Eggs of things. Illustrated by Kumin, M. W. New York: Putnam's Sons.

Sexton, A. (1964). More eggs of things. Illustrated by Kumin, M. W. New York: G. P. Putnam.

Stein, G. (2013) (1939). The world is round. Illustrated by Hurd, C. New York: Harper Collins.

Thurber, J. (1950). The 13 clocks. Illustrated by Simont, M. New York: Simon \& Schuster.

Updike, J. (1999) (1965). A child's calendar. Illustrations by Hyman, T. S. New York: Scholastic Inc.

\section{Copyrights}

Copyright for this article is retained by the author(s), with first publication rights granted to the journal.

This is an open-access article distributed under the terms and conditions of the Creative Commons Attribution license (http://creativecommons.org/licenses/by/4.0/). 